\title{
KAJIAN SOSIAL-BUDAYA MASYARAKAT PADA LANSKAP RIPARIAN SUNGAI CILIWUNG
}

\author{
Study Of Social-Cultural \\ Community On Riparian \\ Lanscape Ciliwung River
}

\section{Fittria Ulfa}

Mahasiswa Departemen

Arsitektur Lanskap, Fakultas

Pertanian IPB

Email : fittriaulfah@gmail.com

\section{Nurhayati}

Staf Pengajar Departemen

Arsitektur Lanskap, Fakultas

Pertanian IPB

\section{Hadi Susilo Arifin}

Staf Pengajar Departemen

Arsitektur Lanskap, Fakultas

Pertanian IPB

\begin{abstract}
Bogor as one of the cities with high population density located in the middle of Ciliwung watershed. The use of riparian rivers as undeveloped land has had an impact on the decline in the quality and quantity of blue open spaces. Local knowledge of the community influences the perspective and behavior of the community towards environmental sustainability. The factors that most influence riparian landscape change are the interaction between human activity and the landscape associated with sociocultural activities. The purpose of this study was to analyze the situational and sociocultural activities of riparian Ciliwung River to blue open space. This study will be conducted in the city of Bogor that is on Pulo Geulis and Griya Katulampa. The method that used in this research is descriptive analysis where the data analyzed is obtained from interview and literature study. The results of this study indicate the existence of two socio-cultural interactions in two research sites, in Pulo Geulis settlement and Griya Katulampa housing has diffrent condition of riparian landscape, which was affected by the bio-physical conditions of the landscape. The results indicated that the background character of the community was very influential on the behavior of cummuny to the river and its environment. The background character that affected were the age, education, type of work, origin, tribe, and length of stay. The different of backgroung level education of community has influence to local knowledge, in Pulo Geulis $40 \%$ graduated elementary school while in Griya Katulampa mostly $40 \%$ graduated from high school.
\end{abstract}

\section{PENDAHULUAN}

\section{Latar Belakang}

Pertambahan penduduk yang terus-menerus membawa konsekuensi spasial yang serius bagi kehidupan kota, yaitu adanya tuntutan akan ruang dalam rangka pemenuhan kebutuhan permukiman, rumah tinggal ataupun perdagangan dan jasa (Mokodongan et al. 2014). Pembangunan yang tidak terkendali akan mempengaruhi pola persebaran yang tidak merata hingga penggunaan bantaran sungai sebagai sasaran pembangunan juga dipengaruhi oleh tingginya harga lahan perkotaan dan disertai lemahnya perekonomian sebagian besar masyarakat, memaksa penduduk memanfaatkan lahan kosong seperti daerah bantaran sungai dengan membangun permukiman liar. Berdasarkan Peraturan Menteri PU PR No. 28 Tahun 2015 sempadan sungai merupakan suatu kawasan lindung tepi sungai yang menjadi satu kesatuan dengan sungai. Hilangnya sempadan sungai akibat diokupasi peruntukan lain akan menyebabkan turunnya kualitas air sungai karena hilangnya fungsi filter yang menahan pencemar non-point source.

Kota besar seperti Bogor sangat berpotensi untuk dijadikan daerah permukiman dan juga pembangunan perumahan yang didukung dengan adanya peraturan daerah seperti di kota Bogor pada Peraturan No 1 tahun 2000 tentang Rencana Tata Ruang Wilayah, dimana kota bogor mempunyai fungsi sebagai kota permukiman, perdagangan, kota industri, kota wisata dan kota pendidikan. Kota Bogor meruapakan daerah yang dilalui oleh aliran DAS Ciliwung yang bermuara ke Ibu Kota Jakarta. Tingginya permintaan akan perumahan diperkotaan menyebabkan kebutuhan lahan yang dimanfaatkan untuk pembangunan juga ikut meningkat. Kondisi lahan perkotaan yang terbatas menimbulkan arah persebaran penduduk yang tidak beraturan. Sehingga hal tersebut berdampak terhadap konversi lahan-lahan yang dilindungi menjadi lahan terbangun seperti pada bagian riparian sungai Ciliwung. Kasus yang mengokupasi bantaran sungai di Kota Bogor. Hal tersebut terjadi akibat besarnya pola perubahan lahan pada periode waktu 30 tahun di DAS Ciliwung yaitu perubahan dari badan air/RTB menjadi lahan permukiman sebesar $76,39 \%$ dari total luasan badan air/RTB yang berubah (Arifin 2013) serta kondisi ekonomi masyarakat berpendapatan rendah yang mengakibatkan ketidak mampuan masyarakat membangun atau menyewa tempat tinggal yang layak (Cahya dan Nana 2012).

Manusia sebagai makhluk sosial membutuhkan berbagai hal untuk dapat bertahan hidup, sehingga manusia memiliki kemampuan dalam memodifikasi sumber daya alam. Adanya kebudayaan yang dimiliki oleh manusia, menempatkan manusia pada kedudukan yang unik di alam. Masyarakat riparian sungai yang mengalami berbagai masalah lingkungan akibat dari kebiasaan dalam cara berinteraksi masyarakat dengan lanskapnya 
menimbulkan berbagai keinginan untuk kehidupan yang lebih baik. Latar belakang masyarakat sangat berpengaruh terhadap tingkat pengetahuan yang membentuk prilaku dari masyarakat. Masyarakat bantaran sungai umumnya menjadikan sungai sebagai suatu tempat pembuangan atau disebut dengan konsep water back. Fenomena water front landscape (WFL) dan water back landscape (WBL) ini merupakan dua paradigma yang dipengaruhi oleh persepsi, cara pandang dan perilaku masyarakat dalam mengelola lingkungannya (Arifin 2015). Cara pandang manusia terhadap lingkungannya menjadi faktor yang sangat berpengaruh terhadap keberlanjutan. Kondisi tersebut akan berdampak terhadap aspek lainnya seperti kondisi kesehatan yang buruk, sumber pencemaran, sumber penyebaran penyakit dan perilaku menyimpang, yang berdampak pada kehidupan kota secara keseluruhan.

Kurangnya kepedulian masyarakat tercermin dari perilaku yang ditunjukkan terhadap keberadaan RTB sebagai suatu elemen penting dalam menjaga keseimbangan alam. Peraturan yang telah ada penarapannya tidak berjalan dengan seharusnya. Hal tersebut berdampak terhadap terciptanya suatu

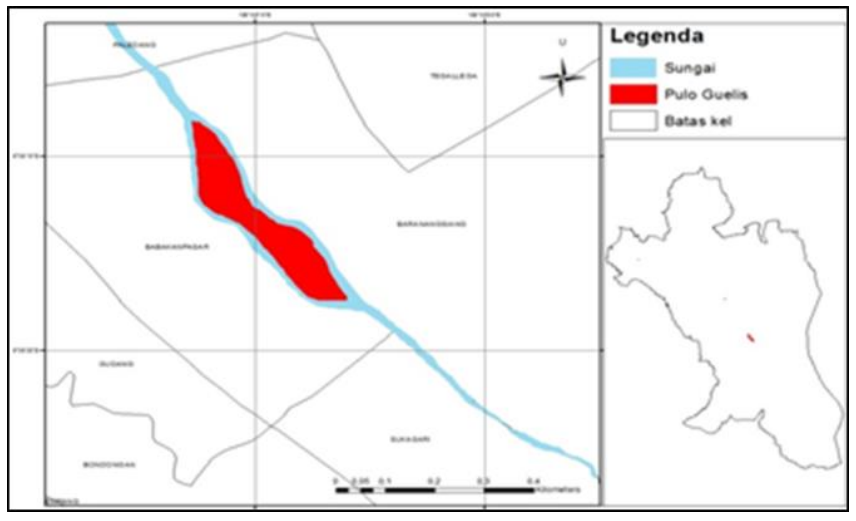

Gambar 1. Peta Lokasi Penelitian Pulo Geulis di Kota

Bogor

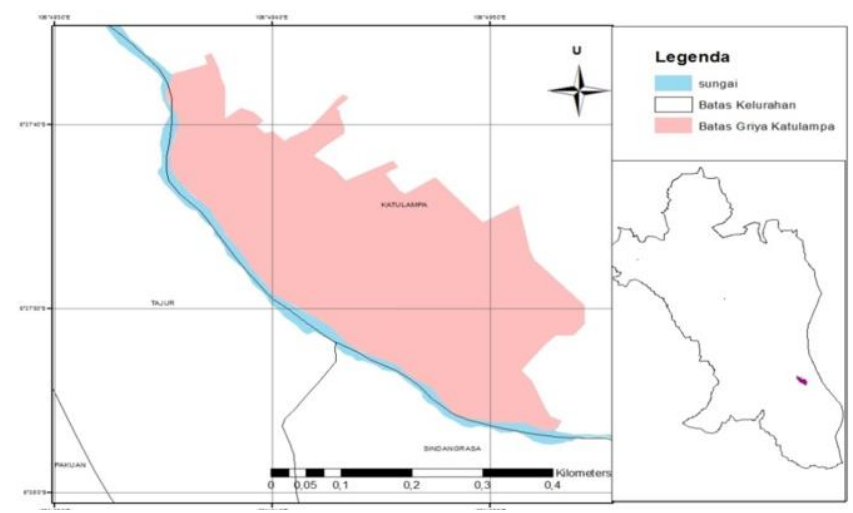

Gambar 2. Peta Lokasi Penelitian Griya Katulampa di Kota Bogor lingkungan yang kumuh dan memprihatinkan. Dimana damapak yang ditimbulkan tidak hanya berbahaya terhadap kerusakan lingkungan akan tetapi juga terhadap kualitas hidup dari masyarakat setempat yang menggunakan sungai sebagai sumber air yang dimanfaatkan dalam aktivitas sehari-hari. Perilaku masyarakat bantaran sungai dalam menjalankan aktivitas sosial, budaya, dan ekonominya akan mempengaruhi keberlanjutan dari RTB baik dari segi kualitas dan kuantitas. Sebagai anggota dari suatu sistem ekologi, manusia pada satu sudut dapat dipandang sebagai penyebab timbulnya berbagai masalah lingkungan hidup, tetapi di sudut lain juga dapat berlaku sebagai pengendali lingkungan (Sunarminto 1993). Penelitian ini dilakukan untuk melihat situasional dan aktivitas sosial-budaya masyarakat yang berbeda yang dipengaruhi oleh latar belakang karakter masyarakat terhadap keberadaan RTB di riparian Sungai Ciliwung. Oleh karena itu, penelitian ini bertujuan untuk menganalisis gambaran situasional dan aktivitas sosial-budaya masyarakat saat ini terhadap keberadaan RTB. Harapannya dengan adanya informasi tersebut dapat menjadi masukan bagi pemerintah Kota Bogor khususnya dalam penataan kawasan riparian sungai Ciliwung, yang disesuaikan dengan akitivitas sosial-budaya masyarakat bantaran sungai, sehingga lanskap riparian sungai dapat terjaga baik secara fisik dan kualitas serta memiliki nilai estetika yang tinggi dan memberi dampak positif terhadap masyarakat sekitar.

\section{METODE}

\section{Lokasi dan waktu penelitian}

Penelitian dilakukan pada dua lokasi di riparian Sungai Ciliwung berdasarkan perbedaan karakter lanskap dan tata spasial serta latar belakang karakter dari masyarakatnya di Kota Bogor yang terletak pada kelurahan Babakan Pasar yaitu di permukiman Pulo Geulis (Gambar 1) dan Kelurahan Katulampa di perumahan Griya Katulampa (Gambar 2). Lokasi penelitian dipilih berdasarkan beberapa penelitian sebelumnya yang menunjukkan adanya hasil dari aktivitas interaksi masyarakat terhadap lanskap riparian serta pemanfaatan sumber air dalam aktivitas seharihari. Penelitian dilaksanakan pada bulan Januari - April 2017.

\section{Alat dan Bahan}

Peralatan yang akan digunakan pada penelitian ini, meliputi kamera digital, seperangkat komputer, pesawat tanpa awak (Unmanned Aerial Vehicle)/drone jenis Quadcopter, Global Positioning System (GPS), serta berbagai software seperti ArcMap 10.4, S, Microsoft Word 2013, dan Microsoft Excel 2013. Bahan yang digunakan 
dalam penelitian ini adalah foto udara dari drone (citra UAV) dan kuesioner.

\subsection{Metode Analisis Data}

Analisis situasional dan aktivitas sosial-budaya masyarakatterhadap RTB dilakukan dengan teknik pengumpulan data secara kualitatif, yaitu survei lapang, studi pustaka, wawancara dan kuesioner. Wawancara dan pengambilan data kuesioner dilakukan dengan menggunakan metode purposive sampling, yaitu pengambilan sampel responden dengan memilih secara acak pihak-pihak yang memiliki pengaruh besar bagi masyarakat pada titik sampel lokasi penelitian (Ketua RT/RW atau organisasi masyarakat setempat) yang letak RT/RW-nya berada cukup dekat dengan riparian sungai, yaitu dengan jarak sekitar 10-30 meter dari bibir sungai (Ghassanii dan Hadi 2016), batasan umur responden minimal 17 tahun, dan responden merupakan penduduk asli daerah setempat.

Jenis penelitian ini adalah deskriptif, yaitu suatu metode yang meneliti mengenai status dan obyek tertentu, kondisi tertentu, sistem pemikiran atau suatu kejadian tertentu pada saat sekarang. Tujuannya adalah untuk membuat deskripsi atau gambaran secara sistematis, faktual dan akurat mengenai fakta-fakta, sifa-sifat serta hubungan antara fenomena yang diteliti. Metode analisis data yang digunakan adalah analisis deskriptif berdasarkan data yang telah diperoleh baik data dari lapangan (survey dan wawancara) serta data pendukung (sekunder). Adapun bagian yang akan dianalisi nantinya adalah terkait aktivitas sosial-budaya masyarakat dalam berinteraksi dengan lanskap riparian.

\section{HASIL DAN PEMBAHASAN}

\section{Analisis Situasional Lanskap}

\section{Topografi dan Iklim}

Secara geografis daerah aliran Sungai Ciliwung terletak pada $106^{\circ} 47^{\prime} 43^{\prime \prime}-107^{\circ} 0^{\prime} 15^{\prime \prime}$ BT dan $6^{\circ} 6^{\prime} 12^{\prime \prime}-6^{\circ} 34^{\prime} 56^{\prime \prime}$ LS. Sungai Ciliwung merupakan suatu Daerah Aliran Sungai (DAS) dengan luas $368.10 \mathrm{~km}^{2}$ dan panjang 117 $\mathrm{km}$. Kota Bogor merupakan salah satu daerah yang dialiri oleh DAS Ciliwung. Kota Bogor terletak antara $106^{0} 43^{\prime} 30^{\prime}$ BT 106051'00" BT dan 30'30" LS 6041'00" LS, dimana pada pembagian segmen DAS Ciliwung Kota Bogor terletak pada bagian tengah dari DAS.

Secara umum Kota Bogor didominasi oleh dataran rendah yang menyebar di seluruh wilayah administrasi Kota Bogor yatu Kecamatan Bogor Utara, Bogor Selatan, Bogor Timur, Bogor Barat sampai Bogor Tengah dan Tanah Sereal. Kota Bogor terletak diantara 106' 48' BT dan $6^{\prime} 26^{\prime}$ LS serta mempunyai ketinggian rata rata minimal 190 meter, maksimal 350 meter, kemiringan lereng antara $0-3 \%, 4-15 \%, 16-30 \%$ dan di atas $40 \%$.

Curah hujan rata-rata di wilayah DAS Ciliwung yaitu sebesar $2913 \mathrm{~mm} /$ tahun dan termasuk kategori tinggi. Setiap kawasan di DAS Ciliwung memiliki curah hujan yang berbeda-beda. Kota Bogor yang merupakan Ciliwung bagian tengah memiliki curah hujan tang tergolong tinggi hingga mencapai $4100-4400 \mathrm{~mm} /$ tahun (Gambar 3). Berdasarkan klasifikasi Schmidth dan Ferguson, tipe iklim di DAS Ciliwung adalah tipe iklim A, dimana memiliki Bulan Basah ( $\mathrm{CH}>100 \mathrm{~mm} /$ bulan) 10 bulan, Bulan Lembab 2 bulan ( $\mathrm{CH} 60-100 \mathrm{~mm} /$ bulan), dan tidak memiliki bulan kering (BPDAS Citarum Ciliwung 2013).

\section{Bio-Fisik}

Secara umum penggunaan lahan pada daerah DAS Ciliwung didominasi oleh kawasan terbangun berupa permukiman yang mencapai 21466.65 ha atau 55.59\% dari luas total DAS Ciliwung (BPDAS Citarum-Ciliwung 2013). Peningkatan ini didorong oleh adanya peningkatan jumlah penduduk pada DAS Ciliwung sehingga kebutuhan akan tempat tinggal dan fasilitas penunjang lainnya juga meningkat. Begitu juga dengan daerah DAS Ciiwung bagian tengah yang salah satunya meliputi daerah Kota Bogor yang merupakan daerah dengan kepadatan penduduk tinggi. Perluasan lahan permukiman masyarakat berdampak terhadap penggunaan riparian sungai secara ilegal di sepanjang DAS Ciliwung, tidak terkecuali pada kawasan Kota Bogor. Akibat dari pertambahan penduduk berdampak terhadap peningkatan kebutuhan hunian seperti lahirlah permukiman yang berkembang secara organik yang didominasi oleh masyarakat dengan pendapatan rendah dan perumahan-perumahan bagi masyarakat menengah keatas (Gambar 4).

Berdasarkan hasil tangkapan foto udara dapat dilihat tutupan lahan dari Pulo Geulis didominasi oleh lahan terbangun dan hanya sebagian kecil terdapat vegetasi (Gambar 5). Permukiman Pulo Geulis menjadikan seluruh bagian riparian sungai sebagai lahan terbangun baik itu sebagai rumah hunian, fasilitas umum dan lahan perekonomian. Kepadatan penduduk tercermin juga dari kerapatan bangunan yang ada pada permukiman tersebut sehingga masyarakat tidak memiliki ruang publik yang cukup untuk dimanfaatkan sebagai tempat aktivitas sosial dalam kesehariannya. Akibat dari pembangunan tersebut menyebabkan minimnya vegetasi yang tumbuh baik di bantaran sungai atau adanya ruang terbuka hijau (RTH) (Gambar 6). Satu-satunya ruang terbuka hijau yang dinilai cukup baik adalah pekarangan miliki pribadi dari seorang warga di Pulo Geulis. 
'Adapun wilayah padat penduduk lainnya di bagian timur Kota Bogor yang merupakan daerah pinggiran Sungai Ciliwung yang di dominasi oleh perumahan. Griya Katulampa merupakan salah satu perumahan yang letaknya sangat dekat dengan aliran Sungai Ciliwung (Gambar 7). Perumahan ini didesain dan

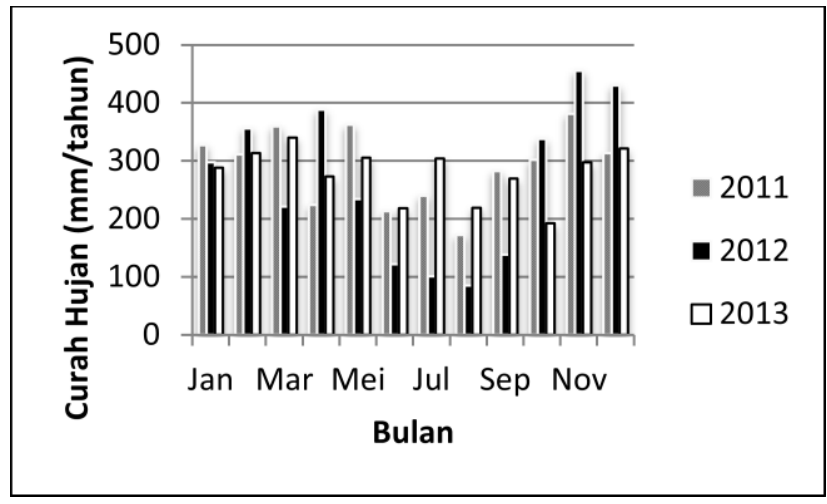

Gambar 3. Curah hujan rata-rata dari tahun 2011-2013

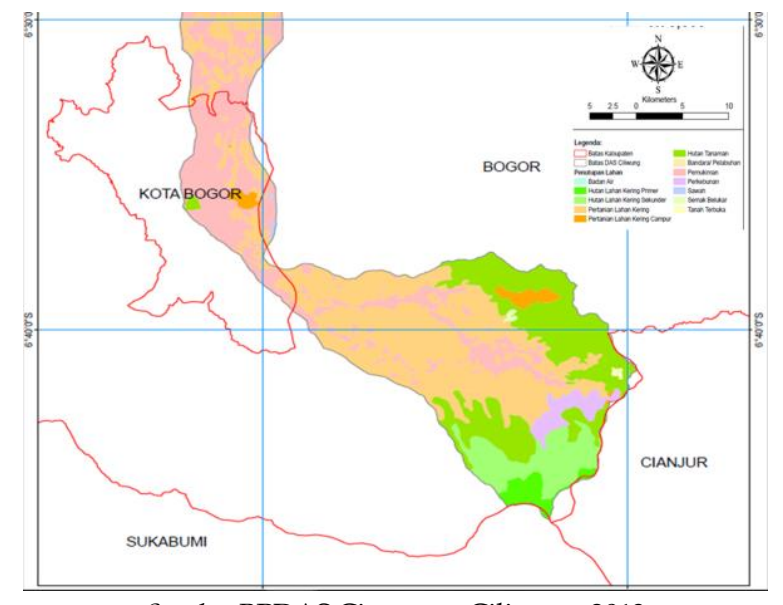

Sumber BPDAS Citarum - Ciliwung 2013

Gambar4. Peta tutupan lahan bagian tengah-hulu DAS Ciliwung

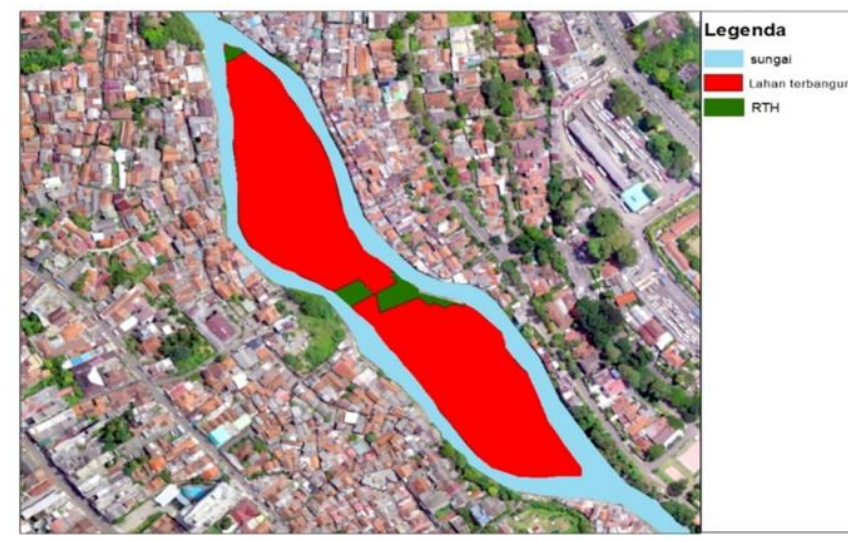

Gambar 5. Tutupan lahan Pulo Geulis direncanakan dengan cukup baik oleh developer. Meskipun perumahan Griya Katulampa termasuk perumahan yang sebagian besar juga didominasi oleh lahan terbangun (rumah, jalan dan fasilitas pendukung) namun perumahan ini diimbangi dengan adanya RTH yang cukup untuk memenuhi terjaganya kualitas lingkungan. Perumahan ini memiliki sumber mata air bawah tanah yang merupakan hasil resapan dari aliran sungai. Hal ini sangat didukung oleh tersedianya jalur hijau di sepanjang sungai dimana vegetasi tersebut menangkap air dan menyimpannya dalam tanah sehingga menjadikannya sumber air bawah tanah bagi perumahan tersebut (Gambar 8).

\section{Analisis sosial-budaya Masayarakat}

Berdasarkan data yang diperoleh dari Rencana Tata Ruang Wilayah Kota Bogor 2009 - 2028 jumlah penduduk pada tahun 2010 sebanyak 938.000 jiwa, sedangkan pada tahun 2015 jumlah penduduk Kota Bogor 1.047.922 jiwa (BPS Kota Bogor 2015). Peningkatan jumlah penduduk menimulkan permasalahan spasial yang dipengaruhi oleh kondisi sosial-budaya masyarakat. Dimana semakin meningkatnya jumlah penduduk maka kebutuhan lainnya akan ikut meningkat dan dipengaruhi oleh kedaan sosial perekonomian masyarakat berdampak terhadap munculnya permukiman-permukiman tidak layak huni hingga layak huni.

Berdasarkan undang-undang No 4 tahun 1992 tentang perumahan dan permukiman, adapun yang disebut sebagai perumahan adalah kelompok rumah yang berfungsi sebagai lingkungan tempat tinggal atau lingkungan hunian yang dilengkapi dengan prasarana dan sarana lingkungan. Permukiman adalah bagian dari lingkungan hidup di luar kawasan lindung, baik yang berupa kawasan perkotaan maupun perdesaan yang berfungsisebagai lingkungan dan penghidupan. Skala perbandingan perumahan dan permukiman, dimana jumlah perumahan sekurang-kurangnya 15-1000 rumah sedangkan permukiman sekurang-kurangnya 1000-3000 rumah. Hal tersebut sesuai dengan PERMEN Perumahan Rakyat Republik Indonesia No. 10 Tahun 2012 terkait penyelenggaraan perumahan dan kawasan permukiman dengan hunian berimbang.

Menurut hasil kajian yang dilakukan oleh Dinas Cipta Karya dan Tata Ruang Kota Bogor, penanganan kawasan kumuh di kota Bogor dibagi kedalam 8 wilayah kumuh. Antara lain Kelurahan Kebon Pedes, Kelurahan Babakan Pasar, Kelurahan Ciwaringin, Kelurahan Sempur, Kelurahan Baranangsiang, Kelurahan Katulampa, Kelurahan Muara Sari, Kelurahan Sindangbarang (Dinas Cipta Karya dan Tata Ruang Kota Bogor 2010). Salah satu permukiman yang 
menjadi kajian penelitian ini adalah permukiman dan perumahan yang berada di DAS Ciliwung di Kota Bogor. Keduanya memiliki dua karakter yang sangat berbeda baik dari segi latar belakang sosial-budaya masyarakat dan jenis tempat hunian.

Berdasarkan data yang diperoleh pada Tabel 1 dapat dilihat bahwa terdapat perbedaan latar belakang karakter dari dua lokasi di riparian Sungai Ciliwung di Kota Bogor yaitu Pulo Geulis dan Griya Katulampa yaitu pada jenis kelamin, umur, tingkat pendidikan, jenis pekerjaan, asal, suku, dan lama tinggal. Persentase tersebut menunjukkan bahwa jenjang tingkat pendidikan yang berbeda dimana di Pulo Geulis 40\% mayoritas lulusan SD sedangkan di Griya Katulampa
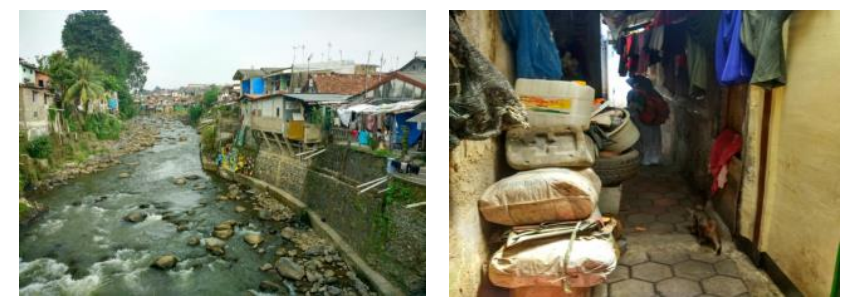

Gambar 6. Permukiman di Pulo Geulis yang didominasi oleh lahan terbangun (kiri) dengan kerapatan yang sangat tinggi (kanan)

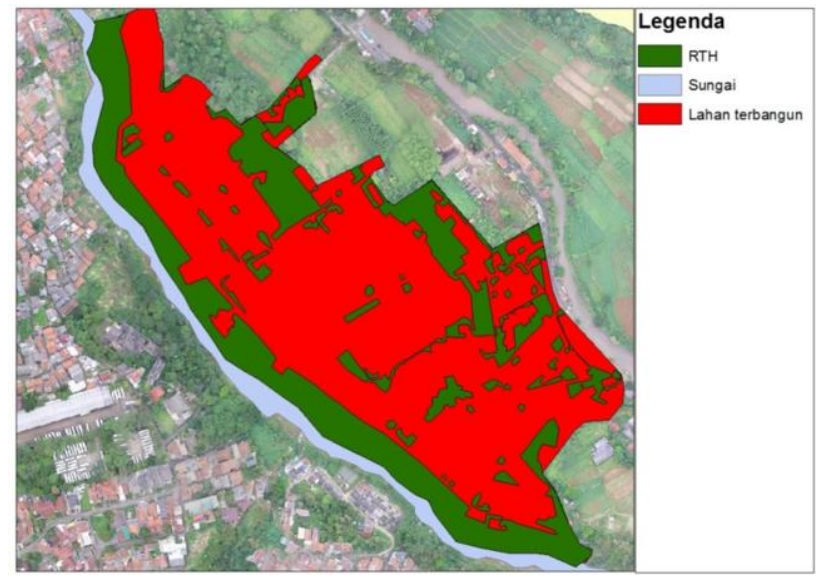

Gambar 7. Tutupan lahan Griya Katulampa

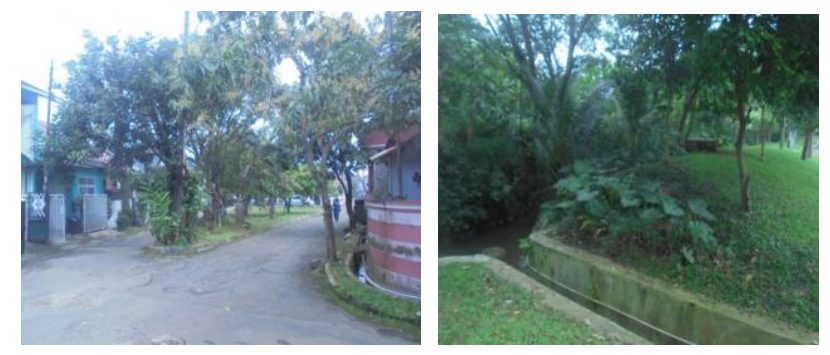

Gambar 8. Perumahan Griya Katulampa dengan ruang terbuka (kiri) dan jalur hijau disekitar bantaran sungai (kanan)
50\% lulusan SMA dan 26.67\% bahkan lulusan perguruan tinggi. Hal tersebut sangat mempengaruhi pengetahuan masyarakat yang mempengaruhi prilaku terhadap lingkungan.

\section{Pulo Geulis}

Pulo Geulis merupakan suatu dataran yang membentuk pulau yang berada ditengah-tengah Sungai Ciliwung yang terbelah. Pulo Geulis salah satu wilayah yang termasuk kedalam permukiman kumuh di Kota Bogor. Pulo Geulis terletak di Kelurahan Babakan Pasar, RW 04 dengan 5 RT. Jumlah penduduk 2640 jiwa dengan luas 3,5 hektar. Pulo Geulis terletak di Kelurahan Babakan Pasar, Kecamatan Bogor Tengah, tepatnya di sebelah selatan Kebun Raya Bogor. Posisi pulau ini masuk ke dalam, secara geografis untuk ke Pulo Geulis dapat dicapai dengan berjalan kaki melewati jembatanjembatan yang menghubungkannya dengan tepian Sungai Ciliwung. Pulo Geulis berada pada kawasan yang sangat strategis dekat dengan Pasar Bogor, dekat dengan Terminal Baranangsiang, dekat dengan tempat wisata Kebun Raya Bogor dan dengan pusat Pemerintahan Kota Bogor. Akses menuju lokasi tersebut dapat ditempuh dari dua arah yaitu melewati dua jembatan yang melitasi Sungai Ciliwung, yaitu dari terminal Baranangsiang dan jalan Suryakencana atau Pasar Bogor (Gambar 9).

Berdasarkan keterangan dari narasumber yang mempelajari sejarah Pulo Geulis, pulau tersebut merupakan sebuah pulau yang sarat akan sejarah yang telah ada sejak kerajaan Sunda, Pajajaran. Bukti lainnya terdapat beberapa peninggalan sejarah yang dipercaya berasal dari kerajaan Pajajaran yaitu berupa batu-batu (Gambar 10) dan patung-patung yang memiliki arti dan lambang dari kekuatan dan kejayaan Kerajaan Pajajaran pada masanya. Banyak peninggalan lainnya yang menjadi bukti bahwa lokasi Pulo Geulis dulunya menjadi salah satu tempat lahirnya peradaban masa kerajaan Sunda.

Berdasarkan hasil wawancara di lapangan dengan narasumber menyatakan bahwa Pulo tersebut merupakan suatu tempat bersejarah bagi beberapa agama leluhur masyarakat kerajaan Sunda. Bukti peninggalan sejarah lainnya yang masih berdiri kokoh sebagai saksi dari kerukunan beragama masyarakat Pulo Geulis yaitu adanya Vihara Maha Brahma atau disebut juga dengan nama Kelenteng Pan Kho Bio yang dibangun pada abad ke-18 (Gambar 11). Sebagaimana kita ketahui vihara biasanya digunakan sebagai tempat peribadatan dan perayaan untuk masyarakat keturunan Tionghoa yang beragama agama Budha, akan tetapi di Pulo Geulis Vihara ikut digunakan oleh masyarakat beragama islam sebagai tempat beribadah. Hal tersebut 
ULFA, NURHAYATI, ARIFIN

Tabel 1 Persentase Karakteristik Responden

\begin{tabular}{|c|c|c|c|}
\hline \multirow{2}{*}{ Karakter Responden } & \multirow{2}{*}{ Katagori } & \multicolumn{2}{|c|}{ Persentase (\%) } \\
\hline & & Pulo Geulis & Griya Katulampa \\
\hline \multirow{2}{*}{ Jenis Kelamin } & Laki-laki & 43.33 & 53.33 \\
\hline & Perempuan & 56.67 & 46.67 \\
\hline \multirow{3}{*}{ Umur (tahun) } & $17-25$ & 6.67 & 6.67 \\
\hline & $26-65$ & 90 & 86.67 \\
\hline & $66-75$ & 3.33 & 6.67 \\
\hline \multirow{6}{*}{ Tingkat Pendidikan } & Tidak Sekolah & 0 & 0 \\
\hline & Lulusan SD & 40 & 6.67 \\
\hline & Lulusan SMP & 36.67 & 6.67 \\
\hline & Lulusan SMA & 16.67 & 50 \\
\hline & Diploma & 6.67 & 10 \\
\hline & Perguruan Tinggi & 0 & 26.67 \\
\hline \multirow{6}{*}{ Jenis Pekerjaan } & Tidak Bekerja & 3.33 & 0s \\
\hline & PNS/ TNI/ POLRI & 0 & 13.33 \\
\hline & Wiraswasta & 23.33 & 20 \\
\hline & Pelajar/Mahasiswa & 333 & 10 \\
\hline & Sektor Informal & 30 & 16.67 \\
\hline & Ibu Rumah Tangga & 40 & 40 \\
\hline \multirow{2}{*}{ Asal } & Penduduk Asli & 73.33 & 16,67 \\
\hline & Pendatang & 26.67 & 83,33 \\
\hline \multirow{4}{*}{ Suku } & Sunda & 86.67 & 53.33 \\
\hline & Tionghoa & 6.67 & 10 \\
\hline & Jawa & 3.33 & 23.33 \\
\hline & Lainnya & 3.33 & 13.33 \\
\hline \multirow{7}{*}{ Lama Tinggal (tahun) } & $01-10$ & 6.67 & 40 \\
\hline & $10-20$ & 10 & 13.33 \\
\hline & $20-30$ & 13.33 & 43.33 \\
\hline & $30-40$ & 20 & 3.33 \\
\hline & $40-50$ & 23.33 & 0 \\
\hline & $50-60$ & 16.67 & 0 \\
\hline & $60-70$ & 10 & 0 \\
\hline
\end{tabular}

menunjukkan bahwa keharmonisan masyarakat Pulo Geulis dalam beragama sangat tinggi hal ini sudah terjalin sejak dulu dan hingga saat ini masih terjaga dengan baik.

Sejak dulu kehidupan masyarakat Pulo Geulis hidup berdampingan dengan sungai dimana sungai menjadi sumber air bagi kehidupan sehari-hari mereka. Masyarakat Pulo Geulis merupakan masyarakat dengan rata-rata perekonomian lemah dengan tingkat pendidikan rendah. Masyarakat pulo Geulis sudah sangat akrab dengan Sungai Ciliwung dimana masyarakat memanfaatkan sungai bahkan untuk dikonsumsi akan tetapi sekarang hanya dimanfaatkan sebagai tempat pemandian umum, mencuci, bermain anak-anak, memancing dan sebagai tempat pembuangan air besar (WC umum). Interaksi masyarakat dengan sungai sudah menjadi kebiasaan sejak dulu dan telah menjadi budaya masyarakat pinggiran sungai. Masyarakat merasa nyaman memanfaatkan sungai dalam aktivitas mereka sehari-hari hal ini di pengaruhi oleh adanya aktivitas sosial yang terjalin di sana antar sesama pengguna sungai saat melakukan aktivitas sehari-hari sehingga sungai menjadi suatu ruang publik bagi masyarakat (Gambar 12).

Intensitas masyarakat berinteraksi dengan sungai sebagai salah satu ruang terbuka biru (RTB) juga dipengaruhi oleh pasang-surut air sungai. Ketika air sungai berlimpah maka masyarakat akan sangat aktif dalam memanfaatkan sungai, namun sebaliknya apa bila sungai kering maka sungai akan terlihat sangat kotor. Tercemarnya sungai merupakan hasil dari aktivitas masyarakat terutama yang berada di sekitar sungai. 
Masyarakat di riparian sungai masih sangat kurang terhadap kesadaran betapa pentingnya menjaga lingkungan yang menjadi dari bagian hidup mereka sehari-hari. Hal tersebut sangat tergambar pada cara mereka membuang limbah kotoran, limbah rumah

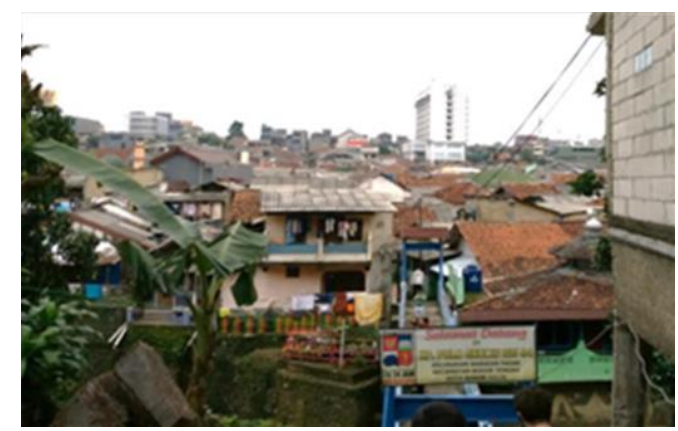

Gambar 9 Permukiman Pulo Geulis yang padat penduduk

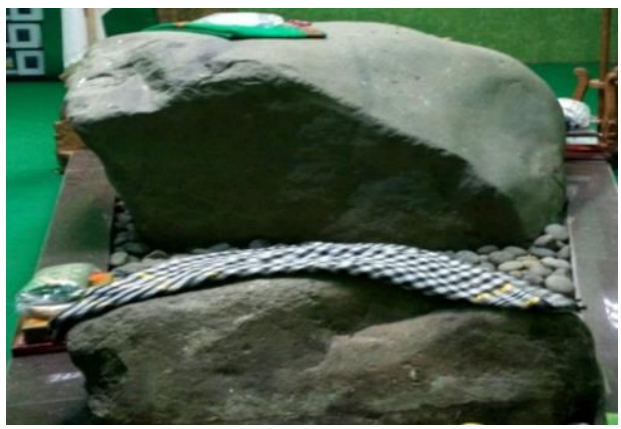

Gambar 10 Bebatuan peninggalan dari kerajaan Pajajaran

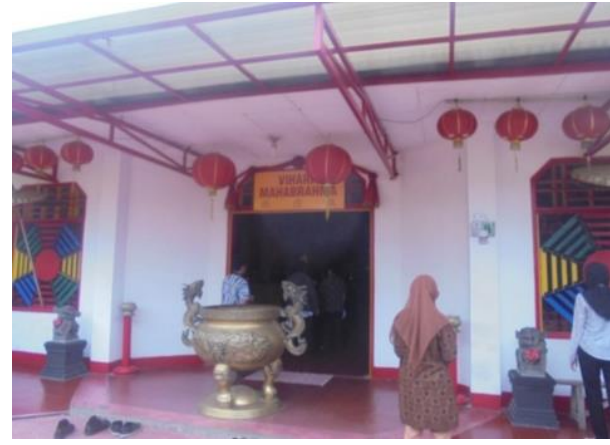

Gambar 11 Vihara Maha Brahma

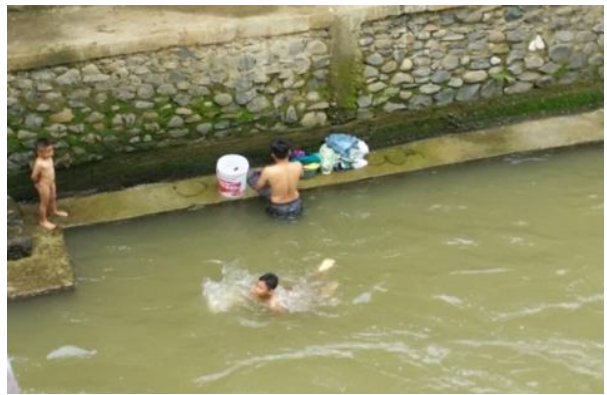

Gambar 12 Aktivitas masyarakat dalam memanfaatkan sungai tangga dan sampah langsung ke dalam aliran sungai sehingga kualitas air sungai menjadi tercemar (Gambar 13 ). Tidak hanya itu dampak yang langsung dapat terlihat adalah polusi visual akibat dari penumpukan sampah yang bahkan tidak hanya berasal dari sekitar pulau namun juga yg terbawa dari hulu Sungai Ciliwung itu sendiri. Umumnya masyarakat memandang sungai sebagai tempat buangan serta berkembangnya mindset yang menganggap lanskap sungai sebagai bagian "belakang" (water back landscape) dalam kehidupan sehari-hari, yakni membangun fasilitas, infrastuktur, sarana prasarana, gedung dan bangunan yang selalu membelakangi lanskap badan air sehingga sungai menjadi bagian belakang, bagian kotor dan tempat pembuangan segala jenis kotoran (Arifin 2014).

Pulau kecil ini merupakan permukiman padat penduduk dengan kerapatan spasial yang nyaris tidak menyisakaan ruang terbuka disekelilingnya. Masyarakat setempat memanfaatkan tembok-tembok, dinding rumah dan bahkan jembatan penyebrangannya dan menjadi lebih menarik dengan konsep kampung pelangi yang merupakan kreatifitas dari masyarakat menjadikan tempat hunian mereka menjadi lebih menarik. Hal ini tidak lepas dari perhatian dan dorongan PEMKOT Bogor yang memiliki keinginan menjadikan kawasan Pulo Geulis ini menjadi salah satu objek wisata (Gambar 14).

\section{Griya Katulampa}

Perumahan Griya Katulampa merupakan perumahan yang telah direncanakan dan dibangun oleh developer. Perumahan ini sudah mulai ditempati oleh masyarakat sejak tahun 1990. Griya Katulampa memiliki sumber daya alam berupa mata air yang berasal dari bawah tanah (ground water) (Gambar 16). Perumahan tersebut terletak di Kelurahan Katulampa RW 10 dan 13 RT. Perumahan ini berada dekat dengan aliran Sungai Ciliwung dimana RT yang paling dekat dengan riparian sungai dan letak mata air adalah RT 4, 5, 10 dan 13. Jumlah penduduk Griya Katulampa 2.257 jiwa dengan 460 kepala keluarga dan luas 14,12 hektar. Perumahan ini memiliki RTH yang cukup baik terutama jalur hijau disepanjang sungai yang tidak beralih fungsi menjadi lahan terbangun. RTH yang terjaga cukup baik pada perumahan ini sangat mendukung dalam menjaga keberlanjutan dari ketersediaan air bawah tanah yang merupakan resapan dari Sungai Ciliwung. Sumber mata air ini dulunya dimanfaatkan oleh masyarakat setempat untuk memenuhi segala kebutuhan air bagi kehidupan mereka. Sumber mata air yang dimiliki aliri kerumahrumah dengan menggunakan pipa-pipa dengan metode sederhana (Gambar 15). 
Masyarakat Griya Katulampa Sebagian besar merupakan masyarakat pendatang yang berasal dari luar Kota Bogor. Latar belakang dari masyarakat tersebut sangat beragam baik dari segi, jenjang pendidikan, asal daerah dan tingkat perekonomian. Masyarakatnya berpendidikan, suku dan agamanya yang beragam serta tingkat perekonomian tergolong kedalam masyarakat menengah-ke atas. Hal tersebut sangat berpengaruh terhadap cara masyarakat Griya Katulampa dalam berinteraksi terhadap RTB. Masyarakat berprilaku lebih arif dalam memperlakukan dan pengelolaan sumber air serta memiliki tingkat kepedulian yang lebih terhadap ketersediaan sumber air secara berkelanjutan (Gambar 16). Sebagai dasar dari kerangka kerja sosial ekologi untuk membangun lanskap yang berkelanjutan dan seimbang, harus memiliki suatu konsep lanskap yang dapat mewakili hubungan antara manusia dengan alam yang saling mendukung antara satu dan lainnya (Bohnet dan Doughglas 2007).

Masyarakat Griya Katulampa memanfaatkan sumber air yang berlimpah tidak hanya untuk kebutuhan seharihari (konsumsi dan mencuci) tetapi juga untuk hal yang lebih produktif untuk mengairi tanaman (berkebun) dan budidaya ikan skala kecil (kolam). Hampir setiap rumah warga memiliki kolam ikan yang hasilnya untuk dikonsumsi skala rumah tangga (Gambar 16).

Kawasan perumahan merupakan suatu kawasan layak huni yang menyediakan sarana dan prasarana yang telah direncanakan sejak awal pembangunan. Adapun salah satu tujuan dibangunnya kawasan perumahan yaitu untuk meminimalisir terbentuknya permukimanpermukiman kumuh secara organik. Sesuai dengan pasal 1 ayat 1 UU No. 1 tahun 2011 menyatakan bahwa satu kesatuan sistem yang terdiri atas pembinaan, penyelanggaraan kawasan perumahan, penyelenggaraan kawasan permukiman, pemeliharan, dan perbaikan, pencegahan dan peningkatan kualitas terhadap perumahan kumuh dan permukiman kumuh, penyediaan tanah, pendanaan dan sistem pembiayaan, serta peran masyarakat.

Menurut American Public Association (APHA) rumah dikatakan sehat apabila:

1. Memenuhi kebutuhan fisik dasar seperti temperatur lebih rendah dari udara di luar rumah, penerangan yang memadai, ventilasi yang nyaman, dan kebisingan 45-55

2. Memenuhi kebutuhan kejiwaan

3. Melindungi penghuninya dari penularan penyakit menularyaitu penyediaan air bersih, sarana pembuangan sampah dan saluran pembuangan air limbah yang saniter dan memenuhi syarat kesehatan

4. Melindungi penghuninya dari kemungkinan terjadinya kecelakaan dan bahaya kebakaran, fondasi rumah yang kokoh, tangga yang tidak curam, bahaya kebakaran karena arus pendek listrik, keracunan, bahkan dari ancaman kecelakaan lalu lintas.

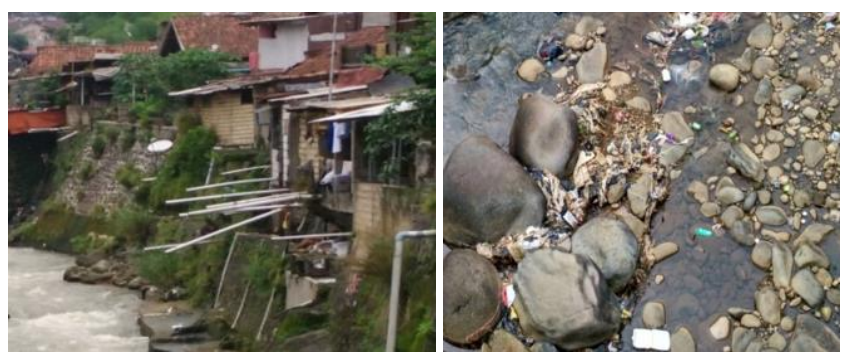

Gambar 13 Pencemaran sungai yang dilakukan masyarakat

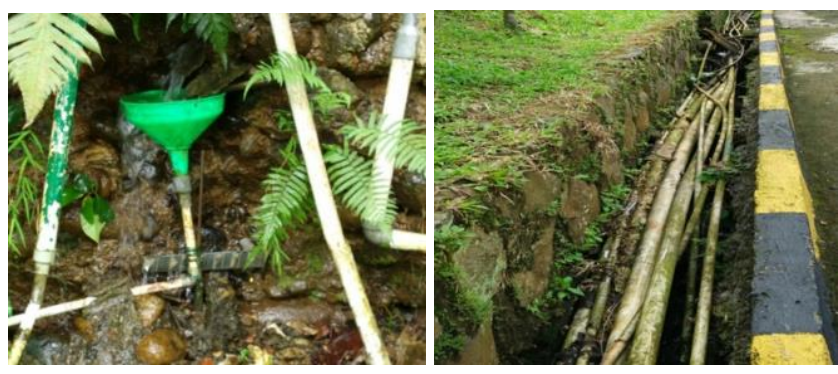

Gambar 14 Griya Katulampa perumahan dengan sumber mata air

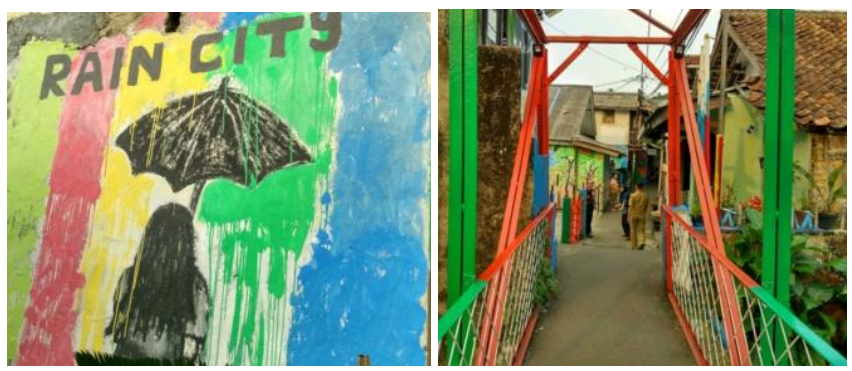

Gambar 15 pencemaran sungai yang dilakukan masyarakat
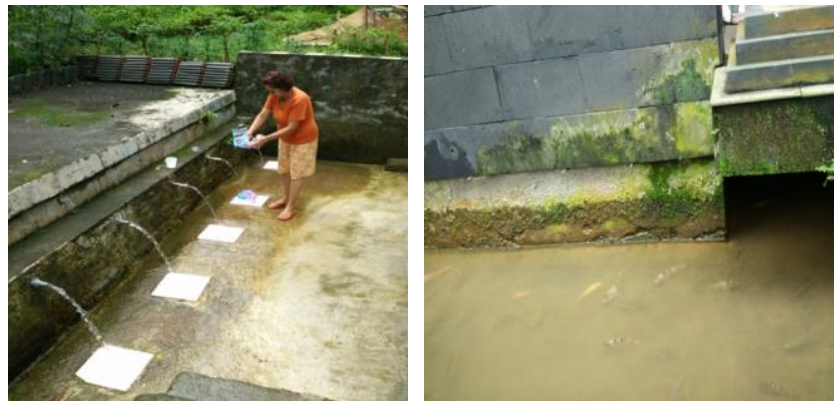

Gambar 16 Griya Katulampa perumahan dengan sumber mata air. 
Berdasarkan dua lokasi tersebut dapat dilihat perbedaan yang sangat kontras antara keduanya dalam berinteraksi dengan RTB dan memenfaatkan sumber air. Kondisi lingkungan dan sumber daya alam yang relatif sama akan menghasilkan cara pengelolaan yang berbeda. Hal ini sangat dipengaruhi oleh latarbelakang dari masyarakat setempat seperti umur, pendidikan, pekerjaan, suku dan lama tinggal.

Pulo Guelis yang merupakan lingkungan permukiman kumuh yang sebagian besar masyarakatnya hanya lulusan sekolah dasar akan sangat berbeda dengan masyarakat perumahan Griya Katulampa yang mayoritas lulusan sekolah menengah ke atas. Tingkat pengetahuan masyarakat akan sangat mempengaruhi perilaku masyarakat terhadap lingkungan sekitarnya. Untuk menghasilkan suatu lingkungan layak huni dibutuhkan perencanaan dan latar belakang dari masyarakat sangat mempengaruhi peran aktifnya dalam berinterasi dengan lingkungan. Aktivitas dari masyarakat sangat berkorelasi terhadap kualitas lingkungan. Dimana lingkungan yang baik akan terus terjaga apabila masyarakatnya tidak hanya memanfaatkan namun juga ikut dalam melestarikan.

Terdapat beberapa hal yang dapat memperbaiki partisipasi masyarakat di bantaran sungai, yaitu (Lorenza et al 2014): (1) Faktor umur dengan kecenderungan bertindak menunjukkan, bahwa golongan muda, perlu dijadikan kader agar kegiatan pengelolaan DAS tetap berkelanjutan; (2) Faktor tingkat pendidikan dengan tingkat pengetahuan menunjukkan, bahwa perlu adanya penyadaran akan pentingnya pendidikan formal bagi generasi penerus; (3) Faktor dukungan masyarakat dengan kecenderungan sikap dan kecenderungan bertindak menunjukkan, bahwa kontrol sosial sangat diperlukan untuk keberlanjutan kegiatan pengelolaan DAS; (4) Faktor tingkat ketersediaan fasilitas dengan kecenderungan bertindak menunjukkan, bahwa peningkatan penyediaan fasilitas sangat diperlukan sehingga kegiatan pengelolaan DAS dapat berkelanjutan; (5) Sumber informasi/komunikasi dengan kecenderungan sikap dan kecenderungan bertindak menunjukkan, bahwa peranan semua pihak yang terlibat sangat penting sebagai pihak utama yang menyebarkan informasi tentang kegiatan pengelolaan wilayah DAS; (6) Tingkat pengetahuan dengan tahap pemanfaatan hasil kegiatan menunjukkan, bahwa kontrol sosial sangat diperlukan untuk keberlanjutan kegiatan pengelolaan DAS; (7) Kecenderungan sikap dengan seluruh tahap partisipasi menunjukkan, bahwa proses penyadaran tentang lingkungan sangat diperlukan untuk meningkatkan kesadaran masyarakat akan pentingnya menjaga dan melestarikan lingkungan sekitar.sebagai aktivitas pengunjung dengan pemilihan jenis rumput yang tidak mudah rusak.

\section{SIMPULAN}

Lanskap riparian Sungai Ciliwung di Kota Bogor sebagian besar telah beralih fungsi menjadi lahan terbangun akibat dari semakin bertambahnya jumlah penduduk sehingga terjadinya perubahan tatanan secara spasial. Munculnya permukiman-permukiman yang berkembang secara ilegal berdampak terhadap terokupasinya riparian sungai menjadi permukiman disepanjang bantaran sungai seperti di Pulo Geulis (Bogor tengah) dan menjamurnya perumahanperumahan seperti Griya Katulampa. Pulo Geulis menjadi permukiman kumuh padat penduduk hasil dari interaksi masyarakat dengan lingkungannya yang kurang peduli terhadap kualitas RTB Sungai Ciliwung. Pengelolaan air yang sudah cukup baik terlihat pada perumahan Griya Katulampa, dimana masyarakatnya menggunakan sumber air yang berasal dari resapan Sungai Ciliwung. Interaksi dari dua kelompok masyarakat yang mendiami suatu lanskap denngan kondisi situasional yang relatif sama sangat dipengaruhi oleh latar belakang dari masyarakatnya yaitu seperti umur, pendidikan, pekerjaan, suku dan lama tinggal.

\section{DAFTAR PUSTAKA}

Arifin HS, Kaswanto, Nurhayati HSA. 2013. Analisis Lanskap Agroforestri: Analisis Ketersediaan Green Water dan Blue Water dalam Manajemen Lanskap yang Berkelanjutan di Daerah Aliran Sungai Ciliwung [Penelitian Strategis]. IPB Press. Bogor (ID): Institut Pertanian Bogor.

Arifin HS. 2014. Revitalisasi Manajemen Ruang Terbuka Biru (RTB) Bagi Perencanaan "Water Front Landscape" yang Berkelanjutan. Seminar Nasional Arsitektur Lahan Basah Tepian Sungai; 11-12 November 2014: Palembang: Indonesia.

[BPDAS] Balai Pengelolaan DAS Citarum-Ciliwung. 2013. Rencana Pengelolaan DAS Terpadu DAS Ciliwung. Bogor (ID): Departemen Kehutanan.

Badan Pusat Statistik Kota Bogor .2015. Kota Bogor.

Cahya DL, Nana J. 2012. Penataan Kawasan Kumuh (Pulo Geulis) Kelurahan Babakan Pasar Kecamatan Bogor Tengah Kota Bogor. Planesa. 3(1): $1-10$.

Bohnet I, Douglas MS. 2007. Planning future landscapes in the Wet Tropics of Australia: A SocialEcological Framework. Landscape and Urban Planning. 80:137-152.

Ghassani A, Hadi SA. 2016. Implementasi Rekayasa Sosial dalam Pengelolaan Lanskap Ruang Terbuka 


\section{ULFA, NURHAYATI, ARIFIN}

Biru Bagi Masyarakat di Bantaran Sungai Ciliwung. [Seminar Penelitian]. Bogor (ID): IPB.

Lorenza R, Radjabaycolle, Sumardjo. 2014. Partisipasi Masyarakat Terhadap Kegiatan Pengelolaan Daerah Aliran Sungai Cikapundung di kelurahan Dago Bandung. Jurnal Penyuluhan. 10(1). 43-58.

Mokodongan BK, Rieneke LE, Sela, Hendriek H, Karongkong . 2014. Indentifikasi Pemanfaatan Kawasan Bantaran Sungai Dayanan di Kotamobagu. J Sabua. 6(3): 273-283.

Peraturan Menteri. 1993. Peraturan Menteri Pekerjaan Umum Republik Indonesia No 63 Tahun 1993. Peraturan Menteri. 2015. Peraturan Menteri Pekerjaan Umum dan Perumahan Rakyat Republik Indonesia No 28 Tahun 2015.

Peraturan Pemerintah. 2011. Peraturan Pemerintah Republik Indonesia No 38 tahun 2011 tentang Sungai.

Sunarminto T. 1993. Studi Sosial Budaya Masyarakat dalam Upaya Konservasi Biodiversity. Media Konservasi. 2(2): 113-116. 